American Journal of Applied Sciences 5 (8): 1047-1051, 2008

ISSN 1546-9239

(C) 2008 Science Publications

\title{
Effect of Storage Time and Temperature on Serum Analytes
}

\author{
Abdoljalal Marjani \\ Department of Biochemistry and Biophysics, Faculty of Meicine, \\ Biochemical and Nutritional Research Center, \\ Golestan University of Medical sciences, Gorgan, Golestan Province, Iran
}

\begin{abstract}
Information on the measured concentration of serum analytes during storage of serum samples is often incomplete and sometimes contradictory. The 10 analytes have not studied in this area in healthy subjects. The aim of present study was designed to determine the effect of storage time and temperature on the laboratory results of 10 analytes in sera from apparently healthy adult males in city of Gorgan.We studied the effect of storage temperature and time on the measured concentration of 10 serum analytes (2006). Serum was separated from the clot within $20 \mathrm{~min}$ of the collection. The sera were stored at $4 \pm 1^{\circ} \mathrm{C}$ and $23 \pm 1^{\circ} \mathrm{C}$ for $0,1,2,3,4,5,6,7,8,24,48$ and $72 \mathrm{~h}$, then assayed. Glucose, Phosphorus and creatinine were the least stable and the serum should be determined within $48 \mathrm{~h}$ at $4 \pm 1^{\circ} \mathrm{C}$ and $24 \mathrm{~h}$ at $23 \pm 1^{\circ} \mathrm{C}$ for these analytes. The other analytes were stable for $72 \mathrm{~h}$. Proper storage temperatures and times must be considered for these analytes (glucose, phosphorus and Creatinine) if measurement is not to take place immediately after specimen collection. Beyond this, it is even very useful to check the reliability of technical and instrumental resources that the laboratory will use during the study because molecular alterations of the analytes due to variable storage conditions can cause misleading results.
\end{abstract}

Key words: Serum analytes, storage time, storage temperature

\section{INTRODUCTION}

Laboratory tests are used by clinicians for diagnosis, monitoring and prognosis in patients with different diseases. A number of factors, primarily preanalytical and analytical or normal biological variations affect the accuracy of test results. Preanalytical factors such sample collection and handling, diet, exercise and drugs can all impact a test result. The key characteristics of any test are its bias and imprecision. Bias is primarily an analytical characteristic, in which reported results differ from the actual value. Imprecision, or lack of reproducibility, is due to both physiological and analytical factors ${ }^{[1]}$.

To detect real pathological changes in patients, the preanalytical and analytical variations must be reduced to acceptable levels at which they cause no impact on clinical interpretation of the results. Observational clinical studies can often be greatly enhanced by the inclusion of biochemical analyses in stored serum samples collected from the population being studied. Biochemical analyses can be used to assess risk factor exposure, to control for confounding, or to measure the effects of bias. In randomized trials, biochemical analyses can be used to monitor the safety and biochemical efficacy of treatment. Standard guidelines for blood sample handling state that plasma or serum should be separated (20-30 min) from cells as soon as possible after clot formation is complete to avoid clotinduced changes in the concentration of serum analytes $^{[2]}$. Whilst this is necessary for particular analytes, it might be assumed that many blood analytes deteriorate within a matter of $h$ in unseparated samples kept at ambient temperature. For most routine assays in a clinical laboratory, serum is the sample.

The laboratory receives the specimen in the form of whole blood and then separates the serum from the clot by centrifugation. For clinically useful and reliable test results, the interval between blood collection and serum separation must be controlled. Many investigators have studied related changes in some analytes, but the results are controversial. The 10 analytes have not studied in this area in healthy subjects. For this reason the present study was designed to determine the effect of storage time and temperature on the laboratory results of 10 analytes in sera from apparently healthy adult males in city of Gorgan. In this study we tried to findout the quantitative alterations and the useful length of stored serum in different time and temperature on the laboratory results. 


\section{MATERIALS AND METHODS}

The subjects were healthy adult males about 25-50 years old, from a employees of Gorgan Faculty of Medicine (2006). The adult males were instructed to fast overnight until blood collection was completed. 10 $\mathrm{ml}$ of blood was collected from each male (in total 10 adult males) without the use of an anticoagulant. Samples were allowed to clot at room temperature for $20 \mathrm{~min}$. we then centrifuged one sample from each male and analyzed the separated sera of 10 analytes without delay (zero time). In addition one sample from each of the 10 adult males was stored for $0,1,2,3,4,5,6,7,8$, 24, 48 and $72 \mathrm{~h}$ at each of the following temperatures: In fridge with $4 \pm 1^{\circ} \mathrm{C}$ which was set up especially for this project and in laboratory bath with $23 \pm 1{ }^{\circ} \mathrm{C}$. We determined the concentration of Glucose ${ }^{[3]}$, Urea ${ }^{[4]}$, Uric Acid ${ }^{[5]}$, Creatinine ${ }^{[6]}$, Albumin $^{[7]}$, Total protein ${ }^{[8]}$, Total cholesterol ${ }^{[9]}$, Calcium ${ }^{[10]}$, Phosphorus ${ }^{[11]}$ and Triglyceride $^{[12]}$ in serum using laboratory kits and spectrophotometry technique (model JENWAY, IOS UV/VIS) in the laboratory of Biochemistry(Faculty of Medicine). The samples showed visible hemolysis was excluded from the study. Data were analyzed using paired t-test for comparison of different storage time and temperature. Results were considered significant when $\mathrm{p}<0.05$.

Assay analyte procedures: The different assay analytes in this study were as follow:

Glucose measurement: The enzyme glucose oxidase catalyzes the oxidation of glucose to gluconic acid. Addition of the enzyme peroxidase, phenol and 4aminoantipyrine results in the formation of a colored compound (quionone) that can be measured and its absorbance was determined at the wavelength of 500 nm.

Urea measurement: The enzyme Urease changes the urea to ammoniac and $\mathrm{CO}_{2}$. Addition of the enzyme glutamate dehydrogenase, ó-ketoglutarateand NADH results in the formation of a L-glutamate and NAD that can be measured and its absorbance was determined at the wavelength of $340 \mathrm{~nm}$.

Uric acid measurement: The enzyme Uricase catalyzes the oxidation of uric acid to allantoine. Addition of the enzyme peroxidase, dichloro 2 hydroxybezen sulfonic acid and 4-aminoantipyrine results in the formation of a colored compound (quionone) that can be measured and its absorbance was determined at the wavelength of $510 \mathrm{~nm}$.
Creatinine measurement: Creatinine react with picrate ion in an alkaline medium to yield an orange-red complex. Whose absorbance is measured at $510 \mathrm{~nm}$.

Albumin measurement: Serum albumin reacts with bromcresol green (BCG) to form a colored compound that can be measured and its absorbance was determined at the wavelength of $630 \mathrm{~nm}$.

Total protein measurement: The biuret method depends on the presence of peptide bonds, which react $\mathrm{Cu}++$ ions in alkaline solutions to form a colored product whose absorbance is measured at $550 \mathrm{~nm}$.

Total cholesterol measurement: The enzyme cholesterol esterase catalyzes the cholesterol ester to cholesterol and fatty acid. Addition of the enzyme cholesteroloxidase results in the formation of 4cholesten-3-one and $\mathrm{H}_{2} \mathrm{O}_{2}$. Addition of the enzyme peroxidase, phenol and 4-aminoantipyrine results in the formation of a colored compound (quionone) that can be measured and its absorbance was determined at the wavelength of $500 \mathrm{~nm}$.

Calcium measurement: Colorimetric measurement, with methylmol blue. that can be measured and its absorbance was determined at the wavelength of 612 nm.

Phosphorous measurement: One of the used methods for serum inorganic phosphate are based on the reaction of phosphate ions with ammonium molybdate to form a phosphomolybdate complex.

Triglyceride measurement: The enzyme lipase catalyzes the triglycerides to glycerol and fatty acid. Addition of the enzyme glycerokinase results in the formation of glycerol-3-phosphate. Addition of the enzyme glycerol-3-phosphate oxidase results in the formation of dihydroxyacetone phosphatet and $\mathrm{H}_{2} \mathrm{O}_{2}$. Addition of the enzyme peroxidase, N-ethy-1-Nsulfopropy $1 \mathrm{~N}$-anisidine and 4-aminoantipyrine results in the formation of a colored compound (quionone) that can be measured and its absorbance was determined at the wavelength of $546 \mathrm{~nm}$.

\section{RESULTS AND DISCUSSION}

The effects of storage time and temperature on results for the following assays were not statistically significant: Urea, Uric Acid, Calcium, Total protein, Albumin, Triglyceride and Total cholesterol. 
Statistically significant changes as compared with the initial time values (Table 1) were noticed for 3 constituent (Table 2 and 3). For urea, Uric Acid, Calcium, Total protein, Albumin, Triglyceride and Total cholesterol there was no effect on samples stored at $4 \pm 1^{\circ} \mathrm{C}$ and $23 \pm 1^{\circ} \mathrm{C}$ for as long as $72 \mathrm{~h}$ (Table 2 and 3 ). Tests that were suitable for analysis at $48 \mathrm{~h}$ incubation at $4 \pm 1^{\circ} \mathrm{C}$ but not suitable for analysis at $48 \mathrm{~h}$ incubation at $23 \pm 1^{\circ} \mathrm{C}$ (suitable for analysis at $24 \mathrm{~h}$ ) were glucose, phosphorus and creatinine (Table 2 and 3 ).

There is a lack of consensus regarding the most appropriate specimen type for analysis of many biochemistry analytes. Information on the stability of serum analytes during storage of serum is often incomplete and sometimes contradictory.

In this study, effect of storage at room temperature $\left(23 \pm 1^{\circ} \mathrm{C}\right)$ and refrigeration $\left(4 \pm 1^{\circ} \mathrm{C}\right)$ for 0,1 , $2,3,4,5,6,7,8,24,48$ and $72 \mathrm{~h}$ on 10 sera analyses were investigated. In this study we found that of the 10 sera analytes that we measured, only glucose, creatinine and phosphorus were affected by storage at $4 \pm 1^{\circ} \mathrm{C}$ and $23 \pm 1^{\circ} \mathrm{C}$ for $48 \mathrm{~h}$ and $24 \mathrm{~h}$, respectively. Glucose was decreased after $48 \mathrm{~h}$ and $24 \mathrm{~h}$ at $4 \pm 1^{\circ} \mathrm{C}$ and $23 \pm 1^{\circ} \mathrm{C}$,

respectively. Creatinine and phosphorus were increased after $48 \mathrm{~h}$ and $24 \mathrm{~h}$ at $4 \pm 1^{\circ} \mathrm{C}$ and $23 \pm 1^{\circ} \mathrm{C}$, respectively. An important advantage of this study when compared with those already published was the number of different storage times. Donnelly et al. ${ }^{[13]}$ investigated the stability of 25 analytes from serum of healthy donors and stored at room temperature and $4^{\circ} \mathrm{C}$ over 48 h, 14 days and 4 months, respectively.

Table 1: Assay values in sera separated immediately after collection (Zero time) from 10 healthy males (with reference intervals ${ }^{1}$ )

\begin{tabular}{lcc}
\hline Analyte & $\begin{array}{c}\text { Mean } \pm \text { Standard } \\
\text { Deviation }\end{array}$ & $\begin{array}{c}\text { Reference } \\
\text { intervals }\end{array}$ \\
\hline Glucose $\left(\mathrm{mg} \mathrm{dL}^{-1}\right)$ & $84.74 \pm 0.56$ & $70-105$ \\
Urea $\left(\mathrm{mg} \mathrm{dL}^{-1}\right)$ & $34.96 \pm 0.81$ & $15-45$ \\
UricAcid $\left(\mathrm{mg} \mathrm{dL}^{-1}\right)$ & $4.62 \pm 0.27$ & $3-7$ \\
Creatinine $\left(\mathrm{mg} \mathrm{dL}^{-1}\right)$ & $0.87 \pm 0.03$ & $0.6-1.3$ \\
Total cholesterol $\left(\mathrm{mg} \mathrm{dL}^{-1}\right)$ & $179.40 \pm 3.71$ & $150-260$ \\
Triglyceride $\left(\mathrm{mg} \mathrm{dL}^{-1}\right)$ & $93.70 \pm 2.75$ & $60-165$ \\
Total protein $\left(\mathrm{g} \mathrm{dL}^{-1}\right)$ & $7.61 \pm 0.12$ & $6.4-8.3$ \\
Albumin $\left(\mathrm{g} \mathrm{dL}^{-1}\right)$ & $4.22 \pm 0.38$ & $3.5-5.2$ \\
Calcium $\left(\mathrm{mg} \mathrm{dL}^{-1}\right)$ & $9.21 \pm 0.26$ & $8.8-10.2$ \\
Phosphorus $\left(\mathrm{mg} \mathrm{dL}^{-1}\right)$ & $3.44 \pm 0.29$ & $2.7-4.5$ \\
\hline 1-Method-specific reference intervals established by commercial kits \\
2-mg dL ${ }^{-1}\left(\mathrm{milligram} /\right.$ decilitre), g dL $^{-1}$ (gram/deciliter)
\end{tabular}

Table 2: Assay values changes in analyte concentration over time in sera stored at $4 \pm 1{ }^{\circ} \mathrm{C}$

Time of analysis, (h)

\begin{tabular}{|c|c|c|c|c|c|c|}
\hline Analyte & 1 & 2 & 3 & 4 & 5 & 6 \\
\hline Glucose $\left(\mathrm{mg} \mathrm{dL}^{-1}\right)$ & $84.90 \pm 0.55$ & $84.64 \pm 0.36$ & $84.65 \pm 0.35$ & $84.86 \pm 0.16$ & $84.64 \pm 0.42$ & $84.70 \pm 0.30$ \\
\hline Urea $\left(\mathrm{mg} \mathrm{dL}^{-1}\right)$ & $34.90 \pm 0.55$ & $34.64 \pm 0.36$ & $34.64 \pm 0.36$ & $34.85 \pm 0.16$ & $34.64 \pm 0.42$ & $34.69 \pm 0.29$ \\
\hline UricAcid (mg dL $\left.{ }^{-1}\right)$ & $4.65 \pm 0.25$ & $4.60 \pm 0.22$ & $4.57 \pm 0.22$ & $4.55 \pm 0.22$ & $4.54 \pm 0.23$ & $4.53 \pm 0.23$ \\
\hline Creatinine $\left(\mathrm{mg} \mathrm{dL}^{-1}\right)$ & $0.88 \pm 0.02$ & $0.87 \pm 0.02$ & $0.87 \pm 0.03$ & $0.87 \pm 0.03$ & $0.87 \pm 0.03$ & $0.86 \pm 0.03$ \\
\hline Total cholesterol $\left(\mathrm{mg} \mathrm{dL}^{-1}\right)$ & $180.40 \pm 3.71$ & $180.00 \pm 4.13$ & $179.60 \pm 3.97$ & $179.05 \pm 4.23$ & $179.20 \pm 4.10$ & $178.67 \pm 3.95$ \\
\hline Triglyceride $\left(\mathrm{mg} \mathrm{dL}^{-1}\right)$ & $94.10 \pm 2.60$ & $94.00 \pm 2.82$ & $94.20 \pm 2.85$ & $94.10 \pm 3.03$ & $94.00 \pm 3.29$ & $93.70 \pm 2.40$ \\
\hline Total protein $\left(\mathrm{g} \mathrm{dL}^{-1}\right)$ & $7.61 \pm 0.14$ & $7.56 \pm 0.13$ & $7.57 \pm 0.11$ & $7.54 \pm 0.12$ & $7.49 \pm 0.14$ & $7.45 \pm 0.27$ \\
\hline Albumin $\left(\mathrm{g} \mathrm{dL}^{-1}\right)$ & $4.32 \pm 0.37$ & $4.31 \pm 0.39$ & $4.40 \pm 0.30$ & $4.39 \pm 0.29$ & $4.37 \pm 0.31$ & $4.39 \pm 0.32$ \\
\hline Calcium $\left(\mathrm{mg} \mathrm{dL}^{-1}\right)$ & $9.20 \pm 0.24$ & $9.20 \pm 0.26$ & $9.15 \pm 0.31$ & $9.18 \pm 0.29$ & $9.16 \pm 0.21$ & $9.17 \pm 0.24$ \\
\hline Phosphorus (mg dL ${ }^{-1}$ ) & $3.42 \pm 0.30$ & $3.43 \pm 0.28$ & $3.47 \pm 0.24$ & $3.50 \pm 0.24$ & $3.55 \pm 0.21$ & $3.51 \pm 0.25$ \\
\hline
\end{tabular}

Time of analysis, (h)

\begin{tabular}{|c|c|c|c|c|c|}
\hline Analyte & 7 & 8 & 24 & 48 & 72 \\
\hline Glucose $\left(\mathrm{mg} \mathrm{dL}^{-1}\right)$ & $84.63 \pm 0.33$ & $84.50 \pm 0.25$ & $84.41 \pm 0.34$ & $84.31 \pm 0.37$ & $67.80 \pm 1.75^{*}$ \\
\hline Urea $\left(\mathrm{mg} \mathrm{dL}^{-1}\right)$ & $34.62 \pm 0.33$ & $34.53 \pm 0.30$ & $34.41 \pm 0.34$ & $34.32 \pm 0.35$ & $34.52 \pm 0.34$ \\
\hline UricAcid $\left(\mathrm{mg} \mathrm{dL}^{-1}\right)$ & $4.47 \pm 0.16$ & $4.45 \pm 0.17$ & $4.43 \pm 0.18$ & $4.40 \pm 0.17$ & $4.39 \pm 0.15$ \\
\hline Creatinine $\left(\mathrm{mg} \mathrm{dL}^{-1}\right)$ & $0.87 \pm 0.03$ & $0.87 \pm 0.03$ & $0.87 \pm 0.04$ & $0.87 \pm 0.03$ & $1.61 \pm 0.11^{*}$ \\
\hline Total cholesterol $\left(\mathrm{mg} \mathrm{dL}^{-1}\right)$ & $178.40 \pm 4.14$ & $178.37 \pm 4.27$ & $178.16 \pm 4.24$ & $178.21 \pm 4.35$ & $178.20 \pm 4.27$ \\
\hline Triglyceride $\left(\mathrm{mg} \mathrm{dL}^{-1}\right)$ & $93.50 \pm 2.46$ & $93.90 \pm 2.64$ & $93.97 \pm 2.48$ & $94.00 \pm 2.42$ & $93.88 \pm 2.27$ \\
\hline Total protein $\left(\mathrm{g} \mathrm{dL}^{-1}\right)$ & $7.47 \pm 0.20$ & $7.48 \pm 0.20$ & $7.46 \pm 0.22$ & $7.50 \pm 0.20$ & $7.51 \pm 0.17$ \\
\hline Albumin $\left(\mathrm{g} \mathrm{dL}^{-1}\right)$ & $4.39 \pm 0.29$ & $4.39 \pm 0.38$ & $4.41 \pm 0.42$ & $4.41 \pm 0.40$ & $4.43 \pm 0.39$ \\
\hline Calcium $\left(\mathrm{mg} \mathrm{dL}^{-1}\right)$ & $9.19 \pm 0.23$ & $9.14 \pm 0.26$ & $8.90 \pm 0.43$ & $9.00 \pm 0.41$ & $8.99 \pm 0.34$ \\
\hline Phosphorus (mg dL ${ }^{-1}$ ) & $3.52 \pm 0.21$ & $3.53 \pm 0.22$ & $3.56 \pm 0.22$ & $3.59 \pm 0.21$ & $4.54 \pm 0.25^{*}$ \\
\hline
\end{tabular}

*: Statistically significant difference after $48 \mathrm{~h}(\mathrm{p}<0.05), \mathrm{mg} \mathrm{dL}^{-1}$ (milligram/deciliter), $\mathrm{g} \mathrm{dL}^{-1}$ (gram/deciliter) 
Am. J. Applied Sci., 5 (8): 1047-1051, 2008

Table 3: Assay values changes in analyte concentration over time in sera stored at $23 \pm 1^{\circ} \mathrm{C}$

\begin{tabular}{|c|c|c|c|c|c|c|}
\hline \multirow[b]{2}{*}{ Analyte } & \multicolumn{6}{|c|}{ Time of analysis, (h) } \\
\hline & 1 & 2 & 3 & 4 & 5 & 6 \\
\hline Glucose $\left(\mathrm{mg} \mathrm{dL}^{-1}\right)$ & $85.05 \pm 0.42$ & $85.09 \pm 0.52$ & $85.18 \pm 0.56$ & $85.08 \pm 0.51$ & $85.10 \pm 0.47$ & $84.83 \pm 0.32$ \\
\hline Urea $\left(\mathrm{mg} \mathrm{dL}^{-1}\right)$ & $35.90 \pm 0.55$ & $35.66 \pm 0.36$ & $35.70 \pm 0.30$ & $35.70 \pm 0.40$ & $35.60 \pm 0.41$ & $35.61 \pm 0.36$ \\
\hline UricAcid $\left(\mathrm{mg} \mathrm{dL}^{-1}\right)$ & $5.70 \pm 0.22$ & $5.66 \pm 0.23$ & $5.53 \pm 0.19$ & $5.59 \pm 0.24$ & $5.51 \pm 0.28$ & $5.53 \pm 0.28$ \\
\hline Creatinine $\left(\mathrm{mg} \mathrm{dL}^{-1}\right)$ & $0.89 \pm 0.03$ & $0.88 \pm 0.03$ & $0.89 \pm 0.03$ & $0.88 \pm 0.03$ & $0.88 \pm 0.03$ & $0.88 \pm 0.04$ \\
\hline Total cholesterol $\left(\mathrm{mg} \mathrm{dL}^{-1}\right)$ & $181.30 \pm 3.56$ & $181.14 \pm 4.13$ & $180.73 \pm 4.02$ & $180.18 \pm 4.20$ & $180.23 \pm 3.97$ & $179.93 \pm 4.01$ \\
\hline Triglyceride $\left(\mathrm{mg} \mathrm{dL}^{-1}\right)$ & $95.00 \pm 2.53$ & $94.99 \pm 2.23$ & $94.63 \pm 3.09$ & $94.91 \pm 3.19$ & $94.92 \pm 3.30$ & $94.61 \pm 2.36$ \\
\hline Totalprotein $\left(\mathrm{g} \mathrm{dL}^{-1}\right)$ & $7.80 \pm 0.16$ & $7.77 \pm 0.14$ & $7.76 \pm 0.13$ & $7.75 \pm 0.14$ & $7.70 \pm 0.15$ & $7.68 \pm 0.26$ \\
\hline Albumin $\left(\mathrm{g} \mathrm{dL}^{-1}\right)$ & $4.42 \pm 0.37$ & $4.41 \pm 0.40$ & $4.51 \pm 0.30$ & $4.48 \pm 0.30$ & $4.48 \pm 0.31$ & $4.49 \pm 0.32$ \\
\hline Calcium $\left(\mathrm{mg} \mathrm{dL}^{-1}\right)$ & $9.44 \pm 0.25$ & $9.44 \pm 0.26$ & $9.39 \pm 0.29$ & $9.51 \pm 0.22$ & $9.40 \pm 0.22$ & $9.40 \pm 0.23$ \\
\hline \multirow[t]{2}{*}{ Phosphorus (mg dL $\mathrm{m}^{-1}$ ) } & $3.52 \pm 0.30$ & $3.54 \pm 0.28$ & $3.57 \pm 0.24$ & $3.60 \pm 0.24$ & $3.66 \pm 0.21$ & $3.60 \pm 0.24$ \\
\hline & \multicolumn{6}{|c|}{ Time of analysis, (h) } \\
\hline Analyte & 7 & 8 & & 24 & 48 & 72 \\
\hline Glucose $\left(\mathrm{mg} \mathrm{dL}^{-1}\right)$ & $84.63 \pm 0.34$ & $84.55 \pm 0.36$ & & $84.50 \pm 0.25$ & $66.58 \pm 1.68 *$ & $66.30 \pm 1.73$ \\
\hline Urea $\left(\mathrm{mg} \mathrm{dL}^{-1}\right)$ & $35.36 \pm 0.33$ & $35.56 \pm 0.31$ & & $35.43 \pm 0.34$ & $35.21 \pm 0.20$ & $35.30 \pm 0.18$ \\
\hline UricAcid $\left(\mathrm{mg} \mathrm{dL}^{-1}\right)$ & $5.56 \pm 0.19$ & $4.45 \pm 0.17$ & & $5.49 \pm 0.21$ & $5.51 \pm 0.21$ & $5.49 \pm 0.21$ \\
\hline Creatinine $\left(\mathrm{mg} \mathrm{dL}^{-1}\right)$ & $0.88 \pm 0.03$ & $0.89 \pm 0.03$ & & $0.89 \pm 0.02$ & $1.56 \pm 0.06^{*}$ & $1.69 \pm 0.10$ \\
\hline Total cholesterol $\left(\mathrm{mg} \mathrm{dL}^{-1}\right)$ & $179.47 \pm 4.19$ & $179.22 \pm 4.41$ & & $78.86 \pm 4.35$ & $179.01 \pm 4.37$ & $179.08 \pm 4.34$ \\
\hline Triglyceride $\left(\mathrm{mg} \mathrm{dL}^{-1}\right)$ & $94.61 \pm 2.75$ & $94.65 \pm 2.67$ & & $94.87 \pm 2.56$ & $94.44 \pm 2.34$ & $94.54 \pm 2.50$ \\
\hline Totalprotein $\left(\mathrm{g} \mathrm{dL}^{-1}\right)$ & $7.68 \pm 0.19$ & $7.70 \pm 0.20$ & & $7.67 \pm 0.22$ & $7.71 \pm 0.20$ & $7.75 \pm 0.20$ \\
\hline Albumin $\left(\mathrm{g} \mathrm{dL}^{-1}\right)$ & $4.50 \pm 0.30$ & $4.49 \pm 0.39$ & & $4.51 \pm 0.43$ & $4.52 \pm 0.41$ & $4.53 \pm 0.39$ \\
\hline Calcium $\left(\mathrm{mg} \mathrm{dL}^{-1}\right)$ & $9.41 \pm 0.23$ & $9.38 \pm 0.25$ & & $9.15 \pm 0.43$ & $9.25 \pm 0.41$ & $9.33 \pm 0.21$ \\
\hline Phosphorus (mg dL ${ }^{-1}$ ) & $3.62 \pm 0.21$ & $3.64 \pm 0.20$ & & $3.68 \pm 0.18$ & $4.61 \pm 0.27 *$ & $4.66 \pm 0.26$ \\
\hline
\end{tabular}

*: Statistically significant difference after $24 \mathrm{~h}(\mathrm{p}<0.05), \mathrm{mg} \mathrm{dL}^{-1}$ (milligram/deciliter), $\mathrm{g} \mathrm{dL}^{-1}$ (gram/deciliter)

All 10 analytes were stable at 2 temperature for specified times. Study of saeed et al. ${ }^{[14]}$ on camel serum showed that albumin, calcium, Phosphours and cholesterol did not change over 9 days when stored at $4-5^{\circ} \mathrm{C}$. At $4-5^{\circ} \mathrm{C}$, creatinine and glucose in camel serum remained stable for 6 days, Total protein for 7 days and blood urea nitrogen for 8 days. At room temperature $\left(23-25^{\circ} \mathrm{C}\right)$. Total protein, albumin, calcium and phosphorus were stable throughout 9 days. Changes in glucose occurred after 3 days. Bobby et al. ${ }^{[15]}$ investigated the stability of 24 analytes after immediate separation of serum and stored at room temperature $\left(25^{\circ} \mathrm{C}\right)$ and analyzed in $0,2,4,8,16,24$, 32, 40, 48 and $56 \mathrm{~h}$ after collection.

All analytes in serum were stable over $56 \mathrm{~h}$ periods. Heins et al. ${ }^{[16]}$ determined the effects of storage time and temperature on 22 serum analytes. In serum at $+9^{\circ} \mathrm{C}$ for seven days the mean changes in phosphorus exceeded significantly. In serum at room temperature, phosphorus, uric acid and triacylglycerols increased continuously. Our results for serum analytes were consistent with those obtained by previous studies ${ }^{[13,15]}$ who investigated these serum analytes. But the results of this study were not in agreement with the results of other investigators ${ }^{[14,16]}$. Changes in the concentration of Glucose, phosphorus and creatinine clinically significant with increasing storage temperature. At temperature $23 \pm 1^{\circ} \mathrm{C}$ the concentration of glucose in serum decreased and the concentration of phosphorus and creatinine in serum increased with increasing temperature when compared with initial results and $4 \pm 1^{\circ} \mathrm{C}$ storage temperature. The decrease of glucose concentration during storage may be related to sensitivity of glucose to temperature or distinguishing of glucose in higher temperaure. It has been suggested that the increase in creatinine concentration during storage is due to non-specific formation of pseudocreatinines ${ }^{[16]}$ with kinetic jaffe reaction.

An abnormally high phosphorus and creatinine concentration could be also result of prolonged storage of serum at room temperature $\left(23 \pm 1^{\circ} \mathrm{C}\right)$. Recording the length of time from collection to separation of each sample might allow appropriate adjustment to be made for the slight increase in concentration of these analytes over time. It should also be noted that room temperature in the present study was $23 \pm 1^{\circ} \mathrm{C}$ which may not be realistic for studies in hotter climates. Some routine tests can tolerate fairly long delays (72 h) in room temperature without changes in analyte content.

Samples for glucose, phosphorus and creatinine should be processed within $24 \mathrm{~h}$ and $48 \mathrm{~h}$. The remaining analytes evaluated were stable for $72 \mathrm{~h}$. Proper storage temperature and times must be considered for these analytes (Glucose, Phosphates and 
Creatinine) if measurement is not to take place immediately after specimen collection. Beyond this, it is even very useful to check the reliability of technical and instrumental resources that the laboratory will use during the study because molecular alterations of the analytes due to variable storage conditions can cause misleading results. In conclusion we hope that the results we have presented will help assess which of the constituents may be assayed in serum stored for prolonged times under commonly encountered storage conditions when such prolonged storage occurs in advertently or is unavoidable.

\section{CONCLUSION}

We recommend that Samples should analyze in the laboratory within preferably $24 \mathrm{~h}$ of collection to ensure valid results. In addition, the turn-around time from sample drawing to reporting the analytical result would be shortened.

\section{REFERENCES}

1. Kaplan, L.A., 1999. Determination and Application of Desirable Analytical Performance Goals: the ISO/TC 212 approach. Scandivian J. Clin. Lab. Investi., 59: 479-482.

2. Young, D.S. and E.W. Bermes, 1999. Specimen Collection and Processing: Sources of Biological Variation. Tietz textbook of clinical chemistry. In: C.A. Burtis and E.R. Ash wood (Eds). Philadelphia: WB saunders company, pp: 42-72.

3. Trinder, P., 1969. Determination of Blood Glucose Using 4-amino Phenazone as Oxygen Acceptor. J. Clin. Pathol., 22: 246-246.

4. Talke, H. and E.G. Schubert, 1965. Eenzymatic Urea Determination in the Blood and Serum in the Warburg Optical Test Klinikal. Wochenschr, 1: 174-5.
5. Trivedi, R.C., L. Rebar, E. Berka and L. Strong, 1978. New Enzymatic Method for Serum Uric Acid at $500 \mathrm{~nm}$. Clin. Chem., 24: 1908-11.

6. Jaffe, M.Z., 1886. Physiol. Chem., 10: 391-392.

7. johnson, A.M., E.M. Rohlfs and L.M. Silverman, 1999. Proteins. Text Book of Ethnical Chemistry, In: C.A. Burtis and E.R. Astwood Editors, 3rd Ed. Philadelphia: W.B. Saunders company, pp: 477-540.

8. Flack, C.P. and J.W. Woollen, 1984. Prevention of Interference by Dextran with Biuret Type Assay of Serum. Clin. Chem., 30: 559-61.

9. Allain, C.C., L.S. Poon, C.S. Chan, W. Richmond and P.C. Fu, 1974. Enzymatic Determination of Total Serum Cholesterol. Clin. Chem., 20: 470-5.

10. Gindler, E.M. and J.D. King, 1972. Rapid Colorimetric Determination of Calcium in Biologic Fluids with Methylthymol Blue. Am. J. Clin. Pathol., 58 : 376-82.

11. Daly, J.A., 1972. Ertingshausen G. Direct Method for Determining Inorganic Phosphate in Serum with the Centrifi Chem. Clin. Chem., 18: 263-5.

12. Bucolo, G. and H. David, 1973. Quantative Determination of Serum Triglycerides by the Use of Enzymes. Clin. Chem., 19: 476-82.

13. Donnelly, J.G., S.J. Soldin, D.A. Nealon and J.M. Hicks, 1995. Stability of Twenty-five Analytes in Human Serum at $22^{\circ} \mathrm{C}, 4^{\circ} \mathrm{C}$ and $20^{\circ} \mathrm{C}$. Pediatr. Pathol. Lab. Led., 15: 869-874.

14. Saeed, A., M. Afzal and S. Akhtar, 1995. Effect of Storage on Some Constituents of Camel Serum. Aust. Vete. J., 72: 212-5.

15. Bobby, L., Jr. Boyanton and E. Kenneth Blick, 2002. Stability Studies of Twenty-four Analytes in Human Plasma and Serum. Clin. Chem., 48: 2242-2247.

16. Heins, M., W. Heil and W. Withold, 1995. Storage of Serum or Whole Blood Samples? Effects of time and temperature on 22 serum analytes. Eur. J. Clin. Biochem., 33: 231-238. 